\title{
Automatic street widening: Evidence from a highway dedication law
}

\author{
Michael Manville \\ University of California Los Angeles \\ mkm253@cornell.edu
}

\begin{abstract}
Cities often require developers to widen streets or make other transportation improvements to account for the traffic impacts of new building. This article examines one parcel-level traffic mitigation law in depth-the highway dedication ordinance of the city of Los Angeles. I first show that the law emerged from a combination of happenstance and political and fiscal constraints, not from persuasive evidence it would be effective. I then show that the traffic predictions underlying the law are often inaccurate, and that, in fact, the standards the law is based on are in some ways unverifiable. Thus the law likely does little to reduce congestion and probably impedes housing development. Finally, I argue that the law persists precisely because its desired outcome is hard to verify: Without measurable goals, planners fall back on a measurable process. Parcel-level traffic mitigation becomes an exercise not in reducing traffic but in ensuring that developers carry out mitigations, regardless of whether those mitigations are effective.
\end{abstract}

\section{Article history:}

Received: July 2, 2015

Received in revised form:

December 16, 2015

Accepted: January 15, 2016

Available online: August 19,

2016

\section{$1 \quad$ Introduction}

Cities regularly evaluate new housing developments by estimating the number of vehicle trips they will create, and then require developers to mitigate those estimated trips. Planners might decide, for example, that a new building will create 35 peak-hour vehicle trips per day, and approve the building only if the developer adds a left-turn lane, or widens a street, or contributes money to public transportation.

This practice is at once common and controversial. The controversy arises because the parcel-level estimates planners make (e.g., 35 daily peak-hour trips) often seem to be wrong, and wrong in the same direction: Cities over-predict driving. Critics contend that based on these over-predictions, planners require developers to provide driving infrastructure (roads, lanes, parking spaces), which then sits underused, invites the vehicle traffic it sought to mitigate, or some combination of both. Because the mitigations are often expensive, they might impede housing development but do little to improve congestion.

Just how inaccurate are such mitigations in practice? And if they are inaccurate, why do they persist? This article examines these questions by analyzing one mitigation procedure in-depth: The highway dedication ordinance of the City of Los Angeles. The dedication law requires developers, Copyright 2016 Michael Manville http://dx.doi.org/10.5198/jtlu.2016.834

ISSN: 1938-7849 | Licensed under the Creative Commons Attribution - Noncommercial License 3.0

The Journal of Transport and Land Use is the official journal of the World Society for Transport and Land Use (WSTLUR) and is published and sponsored by the University of Minnesota Center for Transportation Studies. 
in exchange for building permits, to widen streets the city considers too narrow for traffic levels. The developer cedes, or dedicates, land to the city, then uses that land to physically widen the street. The underlying logic is that new development generates new traffic, and developers should widen streets to account for that impact.

Dedication is of course only one type of parcel-level mitigation, and not the most common. But for three reasons, dedications provide a useful window into mitigation as a broader practice. First, examining one law in-depth allows an exploration of how the ordinance came to be. Shoup (1999) observes that "no one knows" where minimum parking requirements—a consummate parcel-level mitigationcame from, despite their ubiquity. Exploring a law's origins can help explain its motivations, its performance, and why it endures. Second, dedications are a good proxy for many parcel-level mitigations, because they require developers to increase vehicle capacity to reduce congestion. Third, unlike many other mitigations, dedications leave an administrative footprint. Often when planners require mitigations, those mitigations are recorded only in an individual project file, if anywhere. Again using parking requirements to illustrate, almost every city requires developers to build parking, but almost none record their total spaces, where those spaces are, or how often they are occupied (e.g., Chester et al. 2015).

In contrast, when developers dedicate land to the city, the city council must formally accept the dedication, meaning each dedication involves a unique council motion and vote. The resulting council files, which are searchable, provide a complete and consistent picture of the mitigation, and this picture helps address a limitation in other mitigation studies: The absence of data on mitigations themselves.

Much existing research on mitigation analyzes the standards cities use to mandate mitigations. In general, this research finds the standards flawed, and concludes that mitigation is flawed as well (e.g., Shoup 2004; Millard-Ball 2015). But it is possible that mitigation in practice is more accurate than the standards alone suggest. Indeed, one prominent defense of mitigation argues that cities use the standards only as guidelines, and that trained planners deploy them with discretion (Buttke and Arnold 2003). If this assertion is correct, and planners ignore or adjust the standards when they are not necessary, then looking only at the standards might be misleading. Having data on actual street widenings allows a test of that proposition: When evidence suggests that traffic is low, do cities not require wider roads?

The article proceeds as follows. The next section reviews the idea that developers should be required to widen streets or provide other parcel-level mitigations to reduce congestion. I then use archival and secondary materials to trace the history of street widening ordinances in general, and Los Angeles' ordinance in particular. I show in this section that parcel-level mitigation arose largely from fiscal and political constraints, not from theory or evidence suggesting it would be effective. Indeed, even many of widening's early proponents doubted it would reduce congestion. But vehicle ownership was exploding and planners were convinced that something had to be done.

In Section 3 I use a random, statistically significant sample of Los Angeles dedications to show that the city regularly forces developers to widen streets that carry well below their predicted traffic levels. I then use the same data, along with data gathered from developers, to estimate some of the law's costs for housing development. Together this evidence lends support to existing criticism of mitigation as overused and inaccurate.

The article's final section discusses why dedication, and parcel-level mitigation more broadly, endures despite its flaws. Admittedly this section is speculative; bad laws persist for many reasons. But I argue that parcel-level mitigation is an example of what Merton (1957) called "goal displacement" - the nominally desired outcome of the regulation gets replaced by the process of regulation itself. Parcel-level mitigation involves both a transportation prediction and a land-use condition: Planners implicitly or explicitly predict the traffic associated with a new development, and then use that prediction to place conditions on developers. The mitigation can thus be evaluated in two ways: Planners can see if the pre- 
diction is correct, or see if the condition has been met. Ideally they would do both, but in practice ensuring compliance with the conditions is easier than validating the predictions. It is easier to verify that the developer has added street space than it is to verify that the new street space reduced congestion. When the primary concern is not whether the regulation succeeds, but instead whether developers have complied, the regulation's flaws become less important. With the flaws overlooked, the regulation persists.

Some caveats before proceeding: First, Los Angeles' dedication law is explicitly designed to improve traffic flow, which is why I use it to highlight the broader practice of parcel-level traffic mitigation. For the same reason, however, nothing in my analysis invalidates dedication for other uses. There may well be legitimate reasons, unrelated to congestion, for housing developers to cede land to cities. Second, and relatedly, my focus on parcel-level mitigation means my analysis has little bearing on laws that force greenfield developers to construct street networks when they build new subdivisions. These suburban street standards may have their own problems (Southworth and Ben-Joseph 1997; Guo and Schloeter 2011), but these standards do not apply to specific parcels, and are beyond the scope of this article. Finally, some of the specifics I document here may be unique to Los Angeles, and further case research would be necessary to make confident generalizations from all my results.

\section{$2 \quad$ Should cities make housing developers widen streets?}

Laws that take land from housing to expand streets can have two purposes: Increasing access or enhancing mobility. When property is difficult to reach by automobile, building or improving roads can make it more accessible and thus more valuable. It seems sensible and fair in this case for property owners to share the road's costs by contributing land or money. As transportation networks mature, however, and reach a point where most people can get most places, new road space delivers successively smaller improvements in access (Guiliano 1995). Building new roads can greatly increase accessibility; adding lanes to existing roads often does not.

For this reason, cities today are more likely to argue that new road space improves mobility. Adding space can - allegedly - make vehicle travel faster. Property owners still surrender some housing, but the tradeoff now is not more access but less congestion. A priori, there are reasons to doubt this approach. First, mobility benefits accrue largely to motorists, not property owners. Residents often do not want more or faster traffic on their streets, especially at the cost of sidewalks or trees, ${ }^{1}$ and property values are often higher on cul-de-sacs and other streets with lower and slower traffic (Asabere 1990; Wilhelmson 2000; Kim, Park, and Kweon 2007). If more or faster traffic reduces property values, then drivers, not developers, should pay for increased road space, perhaps in the form of tolls or fuel taxes.

Second, shifting land from housing to roads might worsen housing problems more than it improves congestion problems. Many large cities have both bad traffic congestion and high housing prices: In 2012, across 101 large urban areas, the simple correlation between median home value and the Texas Transportation Institute's Travel Time Index (a measure of congestion) was 0.46 . This simultaneous presence of expensive housing and severe congestion suggests that in these cities the demand for housing and the demand for roads both regularly exceed their supply. With housing, this excess demand manifests as high prices, while with road space, which is unpriced, it manifests as recurrent shortages, or congestion.

These facts suggest that cities should address housing problems by increasing supply, and congestion problems by increasing prices. Building more housing makes housing less expensive because housing is traded in private markets; when supply rises prices fall, all else equal (Glaeser 2004). Roads, in contrast, are unpriced common pool resources, and the signature attribute of a commons is that new supply gets rapidly depleted (Ostrom 1990). New road space can reduce congestion in the short term, but does so by reducing the price of peak-period driving, because congestion delay is a large share of peak

${ }^{1}$ e.g., Krekorian (2011). 
driving's total price. As the price falls, more driving occurs, and eventually the street returns to the same level of congestion, albeit with more vehicles (Downs 2004; Duranton and Turner 2011). In sum, moving scarce and valuable urban land from housing to streets shifts it from a priced to an unpriced sector, reducing the probability of it being used efficiently. Taking residential land to widen streets asks housing developers (and by extension housing consumers) to fight congestion by making driving cheaper. In dense areas with many vehicles, this strategy might simply lead developers to pay for a common resource drivers will exhaust.

The demand for housing also has less temporal variance than the demand for roads, suggesting that physical construction is a better response to housing demand than road demand. Housing is consumed in large increments of time, so housing markets lack big off-peak periods characterized by excess capacity. ${ }^{2}$ By contrast, widening a road can only reduce congestion (and do so temporarily) during times when the road would have been congested, and few roads are congested all the time. Even busy roads have periods every day, and sometimes most of the day, when few drivers use them. Street widening is thus a permanent solution to a temporary—albeit recurrent—problem, and wider roads, in addition to not reducing overuse, might exacerbate underuse and the problems that accompany it, such as speeding (Ben-Joseph 1995; Swift et al. 2006; Dumbaugh 2005).

These conceptual problems are compounded when cities try to implement widening. If planners want developers of individual parcels to add road capacity, they must either determine each development's unique contribution to traffic and then exact a mitigation that compensates for it, or predict the overall level of traffic the street will carry, determine the proper width to carry that volume, and then assign developers some portion of that cost. Even setting aside the concern that adding capacity might invite more vehicle travel, these calculations are difficult. City streets often carry through traffic as well as spillover from nearby roads. Thus assigning developments along a road responsibility for all anticipated traffic might make the developer overpay. The alternative, however, is the more difficult task of parcel-level predictions.

It is such predictions that have drawn the most criticism for inaccuracy. Wachs (1990) examined a Los Angeles traffic ordinance that forecast trips created by shopping malls and required developers to either mitigate those trips or pay more than $\$ 2,000$ for each trip that could not be mitigated. Wachs showed that the ordinance predicted more traffic than shopping centers actually generated, and he further showed that random fluctuations in traffic often generated changes larger than those the model attributed to development. Cities using the ordinance could mistakenly charge developers for traffic that did not arise from new buildings.

Shoup (2003) furthered this critique when he analyzed Trip Generation and Parking Generation, the widely used manuals of the Institute of Transportation Engineers (ITE). These manuals purport to predict vehicle trips created by new individual developments. Shoup showed that they were based on flawed samples, and that cities using them would greatly overestimate the driving and parking associated with new development. More recently, Millard-Ball (2015) reinforced this finding, by showing that Trip Generation fails "a simple accounting check": Summing all its predicted trips yields a number 56 percent larger than the total number of trips in the United States.

In response to these criticisms, some researchers have modified ITE and similar standards in the hope of yielding better parcel-level predictions (e.g., Handy 2013; Schneider, Handy, and Shafizadeh 2015). But this approach might skirt a more fundamental problem. Even if planners can correctly predict the trips associated with new developments, the trips are associated with development, not caused by it. Driving trips are caused when people choose to drive, not when developers choose to build, so it isn't clear why developers, rather than drivers, should be responsible for vehicle travel.

The real error in the mitigation process, in short, may not be accuracy but attribution. Congestion

\footnotetext{
${ }^{2}$ The vacation market is an exception, but only 4 percent of American housing is held for seasonal or vacation use.
} 
does not occur because destinations have been built, but because the roads to those destinations are always unpriced, regardless of how many people want to use them (Downs 2004). Blaming congested public roads on developers of private land, and forcing developers to widen streets as a result, is akin to blaming Disneyland for increased air travel, and forcing the theme park to expand runways whenever it adds attractions. Governments neither do this nor need do, because while the demand for air travel is influenced by the popularity of particular destinations, that popularity is reflected in the price of air travel itself.

Making vehicle travel more like air travel would require pricing vehicle travel itself, which elected officials are politically unwilling and sometimes legally unable to do. But if congestion is caused by driving and not development, then parcel-level mitigation may be more symbolic than substantive, a seemingly scientific exercise that lets cities appear to fight congestion and do so without imposing costs on drivers. The costs are instead imposed on developers, who are often the source of ire about congestion anyway. The mitigation thus publicly "punishes" developers, whom the public might believe cause congestion, even if the mitigation does little to make congestion better. Indeed, drivers, if anything, benefit from mitigations because developers are forced to build vehicular infrastructure. This logic has two further implications. First, if mitigation reduces congestion, it likely does so by reducing housing (and by extension population) not driving (Manville, Beata and Shoup 2013). Second, if the mitigation is largely symbolic, its accuracy is immaterial. The goal is to make developers mitigate, not measurably improve congestion.

Importantly, no one needs to intend for mitigation to become symbolic, and most likely no one does. As the next section shows, parcel-level mitigations evolved from legitimate concerns about congestion. Political and economic circumstances led cities to address those concerns on private land rather than on the roads, and at the parcel level rather than at some larger geographic scale. These decisions in turn made the task of mitigation much more difficult.

\section{Origins: The long road to wide streets}

Laws taking private property to expand public streets are some of the oldest in American zoning; even colonial-era cities had ordinances that set aside land for "future street widening" (Home 1969). These laws were intended primarily to increase access rather than improve traffic flow, and in fact the laws were sometimes used to develop property in the street itself. Boston, for instance, widened what is now State Street by more than 100 feet to build a public market in the right of way (Mayo 1993).

Widening streets for mobility, in contrast, was often more controversial. Throughout the 19th century, even as walking cities adopted horsecars and then streetcars, roadways stubbornly retained their dimensions. "Abutters...," McShane observes, "only allowed widening under the rarest of circumstances" (1994, p. 217). The automobile changed this equation: Motor vehicles offered speed and autonomy, but demanded space, and challenged the convention that new vehicles should adapt to existing streets.

In his address to the 1910 National Conference on City Planning, Frederick Law Olmsted Jr. criticized planners for "insisting with needless and undesirable rigidity upon certain fixed standards of width." Narrow streets, he argued, needlessly diluted the automobile's benefits—a problem caused because planners, not automakers, controlled street standards. "The men to whom improved transportation is due," he said, "have so seldom had any responsibility for street planning...that street planning has gone along in the same old routine way, and each improvement in the means of transportation has been fitted to the old Procrustean bed of the street planner" (Olmsted 1910). The automobile's promise, in short, was stifled by the unchanging dimensions of the street; stubborn bureaucrats undermined the men who made cars.

Yet even as he spoke, Olmsted's view was becoming the prevailing wisdom. Planners and engineers 
were abandoning the idea of the multimodal, multiuse street, and viewing roads instead as the car's domain. The men who made cars — as Norton (2008) has shown-became very involved in street planning, and successfully framed congestion as a problem of too few streets rather than too many vehicles. By the late 19th century, cities were spending millions to widen downtown streets, often cutting back buildings and arcading or removing sidewalks (Jakle and Scully 2004; Fogelson 2003, p. 284). Baltimore's planners even saw hope in the city's 1904 Great Fire, which according to the city's chief traffic engineer was "an opportunity to do much to help traffic conditions in the downtown...immediately after the fire was out plans were begun for the widening and opening of a number of streets" (Proceedings of the National Conference on City Planning 1923). New York widened 23rd street in 1910, and two years later, cut back sidewalks on 5th Avenue to add traffic lanes (McShane 1994). In 1917, Harland Bartholomew wrote the first Major Street Traffic Plan, for St. Louis. Bartholomew envisioned wide streets designed primarily, and sometimes exclusively, for automobiles. Cities across the United States soon adopted major street plans, which called for widening many existing streets (Brown 2005; Norton 2008, p. 202).

The apparent wisdom of widening streets to accommodate vehicles was reinforced by the political difficulty of regulating streets to restrain them. Efforts to tame cars rarely ended well. Los Angeles tried restricting traffic rather than widening roads, but a disastrous downtown parking ban in 1920-so unpopular it lasted only a week-made public officials change course (Bottles 1991). Civic leaders formed the Los Angeles Traffic Commission (with Bartholomew and Olmsted as advisors), which after deliberation concluded that street widening was the "city's greatest immediate need" (Los Angeles Traffic Commission 1929, p. 16). The Engineering News-Record, in an editorial about congestion, opined that "the only solution...lies in a radical revision of what a city street is for (Norton 2008, p. 1)." Miller McClintock, dean of American traffic engineers, wrote in 1925 that "the most basic solution for street and highway congestion lies in the provision of greater street area" (Norton 2008, p. 167). An entire seminar at the 1923 National Conference on City Planning was devoted to "How Can Narrow Streets in Business Districts be Widened?" At the same conference, the Chicago Planning Commission's chief engineer predicted steady increases in driving and worried that "our cities provide nothing but streets laid out 30, 50 or 100 years ago, before the automobile was thought of" (Proceedings of the National Conference on City Planning 1923, p. 176-177).

Widening was fraught with certain costs and uncertain benefits. Little evidence suggested it would improve traffic, a point that even its proponents conceded. In 1907, a reporter observed that many newly widened streets appeared not to ease congestion, but "exactly the opposite" (Municipal Journal 1907). Leslie Williams, a member of Los Angeles' Traffic Commission, conceded in 1923 (p. 7) that "there is not much hope of ever catching up with the growing demand of traffic by the mere widening of streets." Nevertheless, that year Los Angeles began widening 75 streets, including 8.5 miles of 9th and 10th streets, which were being expanded from 56 to 86 feet, and "in some instances up to 100 feet." In 1924, Public Works surveyed 233 cities and found that 71 had completed a widening, while another 41 had widenings underway (Jakle and Sculle 2004).

Widening was also expensive. Widenings "cost so much," said New York planner Herbert Swan, "that it is only a question of how many...will break a city" (Proceedings of the National Conference on City Planning 1923). Attempts to spread the costs over landowners met little success. In 1910, for example, New York's mayor proposed a 100-foot wide, \$40-million road through Manhattan (this would be almost $\$ 500$ million in 2015) and asked nearby property owners for the necessary money and land. All refused (McShane 1994, p. 206). In 1929, Pasadena widened part of Colorado Boulevard by 14 feet, condemning or moving back over 90 buildings at a cost of more than $\$ 1.5$ million ( $\$ 20$ million in 2015) (Los Angeles Times 1929). 
Los Angeles first tried to pay for widening with $\$ 25$ million in bonds and special assessments. The city would float $\$ 5$ million in bonds, and property owners would pay the remainder through assessments. Owners could form "Improvement Districts" and petition the city for wider streets. The city would levy additional property taxes in these districts, and the districts would borrow against this revenue to complete the widenings (Spayde 1925). But some property owners resisted the petitions, and because a simple majority of properties in any district could scuttle a widening, the program was soon bogged down in controversy and litigation.

The Great Depression complicated matters further. Property values fell and many Improvement Districts defaulted on their loans. By 1932, over half the districts had failed, and the city and county, also struggling, borrowed from the state to bail them out. The state paid itself back by withholding the city's and county's share of fuel tax revenue. Thus the Depression ended not just the possibility of using Improvement Districts to widen streets but also of using fuel taxes to do so, because the state had used the fuel taxes to rescue the Improvement Districts (LA County Master Plan of Highways 1941).

With assessments and fuel taxes ruled out, Los Angeles—like many cities — turned to zoning, and in particular, setback ordinances. Setbacks prevented buildings from encroaching on private land the city intended to use as streets. Vacant land within setbacks couldn't be developed, and developers demolishing existing structures couldn't rebuild within setbacks. When the property sold, the city took the land in the setback and converted it to street (Figure 1). Thus the turn toward parcel-level approaches to street widening was born, at least in part, of fiscal necessity.

Where the Depression undermined special assessment districts, it made setbacks more effective, because many landowners demolished buildings during the slack economy to reduce their property taxes. This demolition created a relative abundance of empty parcels, letting cities claim land and quickly and inexpensively convert it to streets. Los Angeles County's Master Plan of Highways, written in 1941, noted that "the present rate of absorption [of land for streets] is affected by the very considerable area of the local streets, which now serve vacant land and lots" (LA County 1941, 29). Between 1923 and 1940, Los Angles County acquired 140 miles of right-of way through setbacks, and almost half the county's 45 cities adopted setback laws (LA County 1941).

Setbacks also worked best before land was extensively subdivided, since in these situations land from a single parcel could create a relatively lengthy right-of-way, generating both the most street space and the largest appreciation in land value. County planners noted that setbacks were most effective during "the change in the use of property from farmland or open country to highly improved city lots" (LA County 1941, 83). Once land was developed and broken into smaller parcels, each setback delivered less street.

When setbacks increased access, property owners often willingly surrendered land, a process called voluntary dedication, or "acquisition by deed." These landowners, the County Planning Commission said, were "anxious to have...property served or opened up by a highway and therefore willing to 'give' the land [so] that the county would 'give'...the improvement in turn" (LA County 1941, 82). But in already-developed areas, property owners resented the lost buildable area and challenged setbacks in court. $^{3}$

The US Supreme Court upheld setbacks in 1927's Gorieb v. Fox, and subsequent decisions by lower courts affirmed the broader practice of making developers pay for the traffic impacts of new housing. In Ayres v. Los Angeles, California’s Supreme Court ruled against a subdivision developer who sued Los Angeles for forcing him to widen existing boulevards to improve traffic flow. "The creation and proposed uses of the subdivision," the majority wrote-in an explicit approval of the mobility logic behind widening-"would give rise to traffic and other conditions necessitating the widening of the boulevard...In a growing metropolitan area each additional subdivision adds to the traffic burden" (California

3 "Setback" at this time referred both to laws that prevented building (to establish yards) and that took land to create streets (Home 1969). 
Supreme Court 1949). Although the court asserted that wider streets would alleviate traffic, it provided no evidence to that effect. Nevertheless, the decision reinforced the new consensus in Los Angeles and elsewhere that cities should address congestion by accommodating the automobile and that developers, not drivers, should make those accommodations.

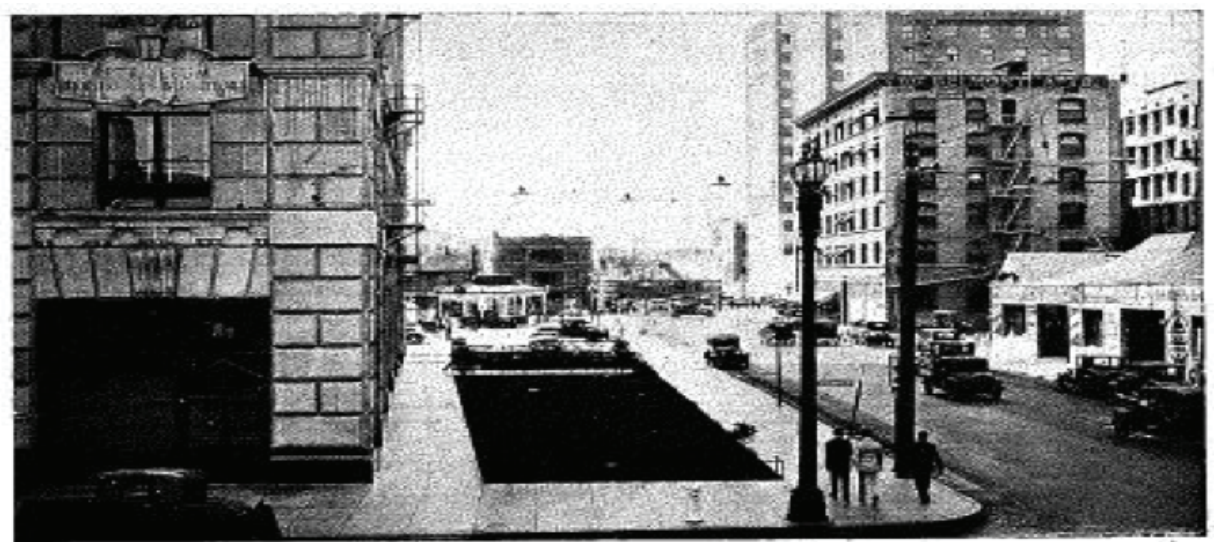

Olympic Boulevard and Flower Street, 1929, Set-Back Ordinance Effective

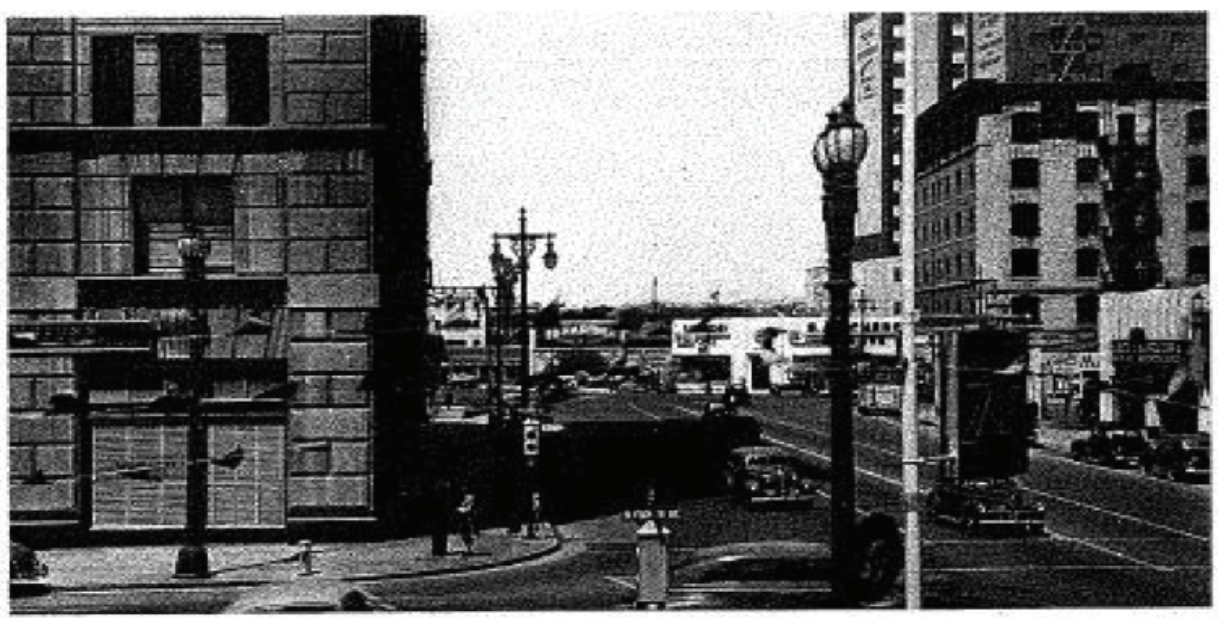

Olympic Boulewand and Flower Sireet, 1941, the Widening Job Completed

Figure 1: A setback ordinance prevents building at an intersection. The city later acquires the land and widens Olympic Boulevard (LA County Master Plan of Roads, 1941).

\subsection{Los Angeles: Compulsory dedication in exchange for approval}

Los Angeles relied on setbacks and voluntary dedications until 1961, when it adopted its current, compulsory dedication law. This law actually originated with a citizen request for more sidewalk space. ${ }^{4}$ In 1957, residents of the Van Nuys neighborhood complained that new multifamily development brought new children, and that without sidewalks these children were unsafely walking on streets (Monlux 1957). In response, both the Bureau of Public Works (BPW) and the Planning Department recommended that "full dedication be required and permanent sidewalks be installed, as a condition precedent to the issuance of a building permit." The Van Nuys Chamber of Commerce agreed, and in February 1959, the BPW reiterated its "strong support for such a law" (Heeb 1961). In September 1959, the Planning Commission suggested that the law also replace the city's current process for street widening.

${ }^{4}$ The research from this section was gathered primarily from the City of Los Angeles archives. The archives devote an entire file related to the dedication law, containing all correspondence and analysis related to its proposal and approval. I augmented this file by searching the archives for "street dedication" and "street widening." 
The resulting ordinance would, according to planning staff, "eliminate irregular street alignments and provide more efficient flow of traffic" (Heeb 1961). A proposal to widen sidewalks for local pedestrians thus became a law to widen streets for through traffic, and the city replaced voluntary dedication in exchange for improvement (for pedestrian access) with compulsory dedication and improvement in exchange for a building permit (for vehicular mobility).

Los Angeles' Building and Safety Department opposed this ordinance, worrying it would reduce buildable area and render some lots undevelopable, by "penalizing owners making land improvements and rewarding those who hold unimproved property." Presciently, the department also worried that the ordinance would create, not eliminate, irregular street alignments, thus hindering maintenance, drainage, and traffic flow (Newstrum 1961). The Planning Department favored the law but acknowledged the validity of these concerns. "While the long-range effects of the proposal will operate to the benefit of the city," planning staff wrote, "in the immediate future, certain problems and possible inequities may develop" (Newstrum 1961). Chief among these was a bias against dense development: Single-family homes would be exempt from the law, so property owners could avoid widening by building less densely (Newstrum 1961).

The planners also conceded that the law might make traffic worse. As parcels were redeveloped, streets might take on sawtooth patterns, wider in some places than others. "Only after the ordinance has been in effect for a period of time, will the street width even out to standard dimensions," they said. Nevertheless, Planning Director John Roberts said it would "meet a very pressing need for development of the city in an orderly manner" and help manage "the problems of both pedestrian and vehicular traffic" (Roberts 1961). The City Council approved the law in 1961, and it became Section 12.37 of the Los Angeles Municipal Code.

Today, dedication works as follows: A developer proposes a multifamily building or a project requiring discretionary approval. ${ }^{5}$ Either of these actions (which often overlap-many multifamily buildings require discretionary approvals) start the process. The planning commission approves many such actions but only after attaching conditions to them. The commission decides on these conditions by circulating the application to other city departments and asking them to propose improvements the developer should make.

One department receiving these requests is the Bureau of Engineering (BOE), a division of the Department of Public Works (successor to the previously mentioned BPW). The BOE examines the street in front of the proposed development, and if the street is narrower than its designated width (the designated width is based on the street's predicted traffic volume), the BOE recommends that street dedication be required in exchange for approval. If the commission accepts this recommendation, the developer must dedicate the land before receiving a building permit. Properties are automatically exempt if dedication would reduce their size by more than 25 percent, or bring the total lot size below 5,000 square feet. In addition, larger parcels can be granted exemptions if developers show, through a city-approved study, that the street can accommodate the next 20 years of traffic at its current width.

Once the land is dedicated, if the city also requires improvement, the developer widens the street before receiving a certificate of occupancy. ${ }^{6}$ Because street improvements are among the last steps a developer takes (improving a street and then constructing a building just damages the street) the developer posts a bond - known as a B-permit — with the city for the estimated amount of the improvement.

\section{$4 \quad$ Street dedication and street traffic}

Los Angeles requires the widening of streets it considers too narrow, a judgment it bases on the city's street standards. The standards, in turn, are based on predicted levels of vehicle travel. This makes street dedication a mitigation that essentially allocates to developers a portion of overall predicted traffic lev-

\footnotetext{
${ }^{5}$ These could include variances, conditional-use permits, or requests to vacate streets (often to eliminate an alley and join two parcels).

${ }^{6}$ In some cases, a previous owner has dedicated land but not improved it, so the city might only require widening.
} 
els, and makes its accuracy dependent on those underlying predictions. Thus one way to evaluate the mitigation is to compare the traffic predictions on streets with dedications with actual traffic counts. A dedication occurring on a street carrying well below its predicted traffic might be unnecessary.

Table 1 shows the street standards and the minimum widths they assign based on predicted vehicle travel. Examining these standards reveals that at least some of the standards are essentially unverifiable. Local streets, which are most numerous and account for the most mileage, have no vehicle count or width criteria, making dedications on local streets impossible to evaluate, and blurring the distinction between local and collector streets. Further, the distinction between collectors and secondary highways is similarly ambiguous, because streets anticipated to carry 10,000-20,000 vehicles per day have no classification. Fehr and Peers (2010) reviewed city documents and concluded that planners often treat these streets as secondary highways, but found no clear reason for this treatment. Thus many streets have no standard widths or predicted traffic volumes.

Table 1: Street classifications in Los Angeles

\begin{tabular}{lccc}
\hline Street Classification & $\begin{array}{c}\text { Predicted Average } \\
\text { Daily Travel (Vehicles) }\end{array}$ & $\begin{array}{c}\text { Standard One-Direction } \\
\text { Width (Lanes) }\end{array}$ & $\begin{array}{c}\text { Standard Width } \\
\text { (Feet) }\end{array}$ \\
\hline Major Highway: Class I & $>50,000$ & 4 & 180 \\
Major Highway: Class II & $30,000-50,000$ & 3 & 132 \\
Secondary Highway & $20,000-30,000$ & 2 & 90 \\
Collector Street & $<10,000$ & 1 & 45 \\
Local Street & no criteria & no criteria & n/a \\
\hline
\end{tabular}

Source: Fehr \& Peers 2010

For the remaining streets, actual traffic levels on dedicated streets can be compared with predicted traffic. Using the Los Angeles City Clerk's Council File Management System, I downloaded the roughly 900 street dedications that took place in Los Angeles between 2002 and 2012. I then randomly selected a statistically significant sample (278) of these dedications, and used the city's Zone Information Map Access System (ZIMAS) to determine the classification of each widened street. I next matched this information with information from the Los Angeles Department of Transportation's (DOT) traffic count archive. For every dedication, I looked for weekday counts at the nearest intersection, from the year of the dedication or shortly after. Almost all of these counts were automatic counts that recorded vehicles over 24 hours. Some of the earlier counts (fewer than 10 percent of the total) were manual counts collected over six hours that the city converted into daily counts. When available, I also collected counts from years before the dedication. I collected up to three counts for each parcel. While for most dedications I was able to find counts from intersections within two blocks, in some cases the closest count was between three and nine blocks away. If the nearest count occurred more than nine blocks away, I did not use it, and I marked the dedication as countless. In total, I assembled 498 counts for 278 dedications.

Using these data, I first compared the traffic counts from the year of the dedication or later with the street's projected traffic. I then compared the average of all counts (before and after dedication) to the street's projected traffic. I separated the more recent counts because counts from earlier years may have been lower (e.g., if, for example, traffic increased post-dedication because the road was wider).

Making these comparisons required resolving the ambiguity around streets anticipated to carry $10,000-20,000$ vehicles per day. I chose to classify these as secondary highways, as the city appears to. Having made this decision, I took the midpoint of each classification's predicted range of vehicles (e.g., for secondary highways, projected to carry between 10,000 and 30,000 vehicles per day, the midpoint was 20,000) and called it the mean predicted vehicle count. I then compared this predicted count to 
the actual counts.

Table 2 shows the results. For every street classification, actual traffic levels were lower than predicted levels, often by substantial amounts. The predicted mean vehicle count for collector streets, for example, was 7,500, but the actual mean count was only 70 percent of that, at 5,300. Similarly, the predicted mean for Class II Highways is 40,000 vehicles, while the actual mean is 30,400 . Only secondary highways had actual counts resembling their predictions. The newer counts are lower than earlier counts, on average, suggesting that traffic is not necessarily increasing over time. Among dedications with multiple counts, the most recent count was smaller than the second-most recent 84 percent of the time. For dedications with three counts, the most recent was smaller than the earliest count 55 percent of the time. ${ }^{7}$ Further, for those classifications with a predicted maximum level of vehicles, no more than 14 percent of counts exceed it. For three of the four classifications with predicted lower bounds of travel, meanwhile, at least half the available counts fell below that predicted minimum. As traffic management exercises, many widenings appear unnecessary.

These results, moreover, are sensitive to how I resolved the ambiguity in the street standards. Treating secondary highways as the standards are written (that is, as carrying between 20,000 and 30,000 vehicles) made the predictions still less accurate. The table shows these revised estimates in parentheses. Now 40 percent of the observed counts for secondary highways fall below the predicted minimum, not 14 , and the share of counts above the predicted maximum is cut in half for both secondary highways and collector streets. Needless to say, a standard whose accuracy can be substantially increased or reduced by exploiting its own internal ambiguity is not very useful.

The table's bottom rows reveal an additional problem: More than 50 dedications-over 20 percent of the total — had no traffic counts at all, suggesting the city required road widening without any traffic information. Almost half the dedications on collector streets had no counts, and almost two-thirds of dedications on local streets took place on segments without traffic counts. Because local streets also have no predictions, this implies that the majority of local widenings were required without standards or data.

Table 2: Traffic levels on dedicated streets, Los Angeles

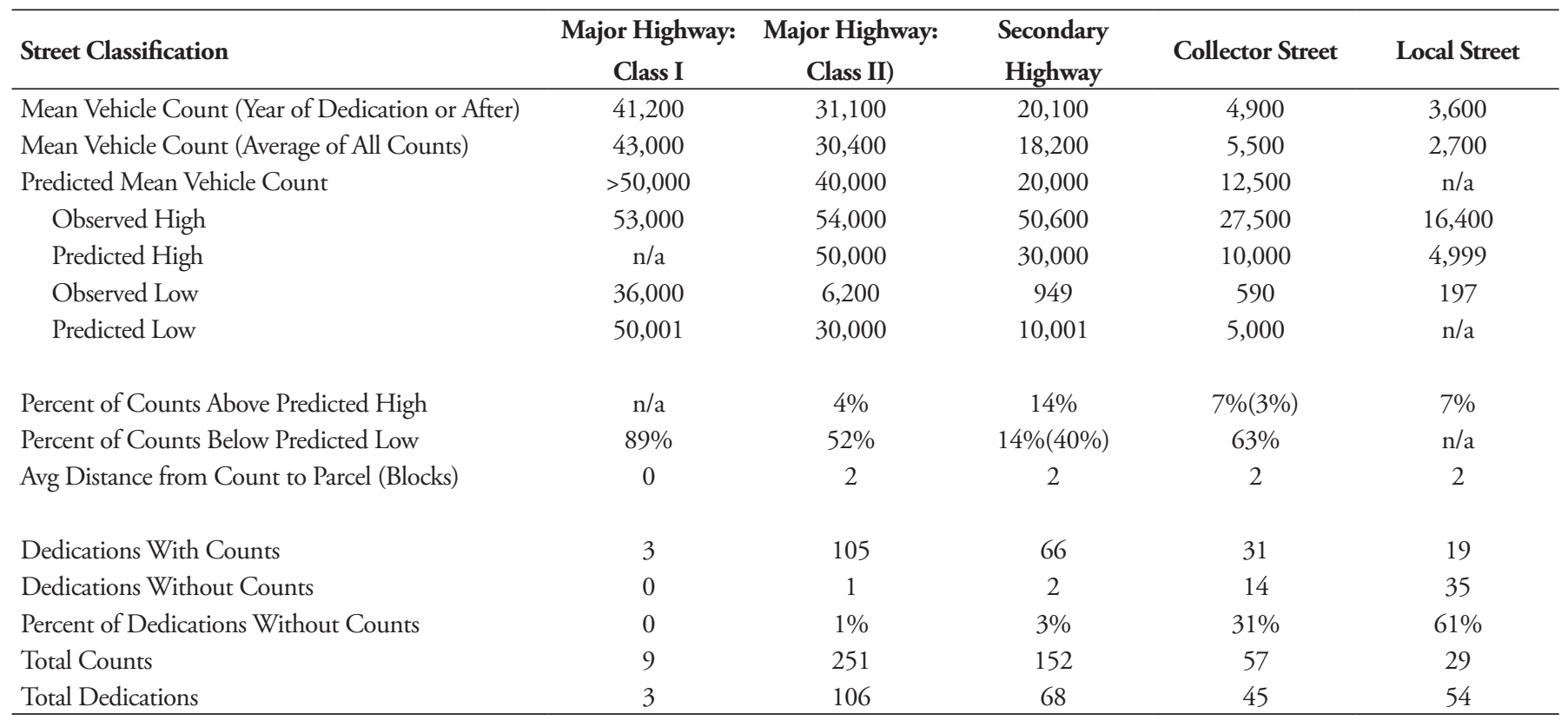

Notes: Figures above 1,000 rounded to nearest hundred. Parenthetical percentages represent alternative interpretation of street standards. Modified Secondary Highways are counted as Major Highways, Modified Collectors as Secondary Highways. Sources: LA DOT Traffic Count Archive, LA City Clerk Council File Management System, LA ZIMAS.

7 These tabulations are not shown in the table. Possibly these falling numbers are artifacts of 2008's recession. However, only 65 of the dedications occurred in 2008 and 2009, and restricting the sample to pre-2008 counts yields the same general pattern: Earlier counts are higher than later counts for three of the five street classifications. 
This evidence lends support to existing critiques of parcel-level mitigation and also to the idea that the exercise is largely symbolic. The standards themselves are in important ways unverifiable; the city appears to require mitigation even when traffic is far below anticipated volumes and even when traffic data are unavailable.

One might counter that I have erred by treating the anticipated traffic volumes, as short-term predictions, when instead they should be considered the design capacity of the road-the amount of traffic the street eventually could carry. This argument has several problems. First, as noted above, traffic levels are likely at least in part endogenous to width. Even ignoring endogeneity, however, the fact remains that a design capacity is a prediction. It may be a prediction with an indefinite time horizon, but this is a drawback, not an advantage, because predictions without time horizons cannot be validated, and predictions that cannot be validated are not useful. Urban land is scarce and valuable, so standards that allocate some of that land to roads should be subject to some form of ground truth. The wisdom of building roads to hold a given capacity of vehicles depends on when and if these vehicles are likely to arrive.

A further issue is that dedications are parcel-level mitigations and only widen streets in front of particular developments. Even if streets were close to capacity and endogeneity was overcome, dedications might still not yield uniformly wider streets. Figure 3 shows a typical dedication and improvement. One parcel is redeveloped, so only the street in front of that parcel is widened. The resulting increment of street is useless for moving vehicles, and becomes additional (free) on-street parking. But the city has already required the developer to build off-street parking (Los Angeles has minimum parking requirements; the driveway is visible in the second image), so even the new parking delivers few benefits.
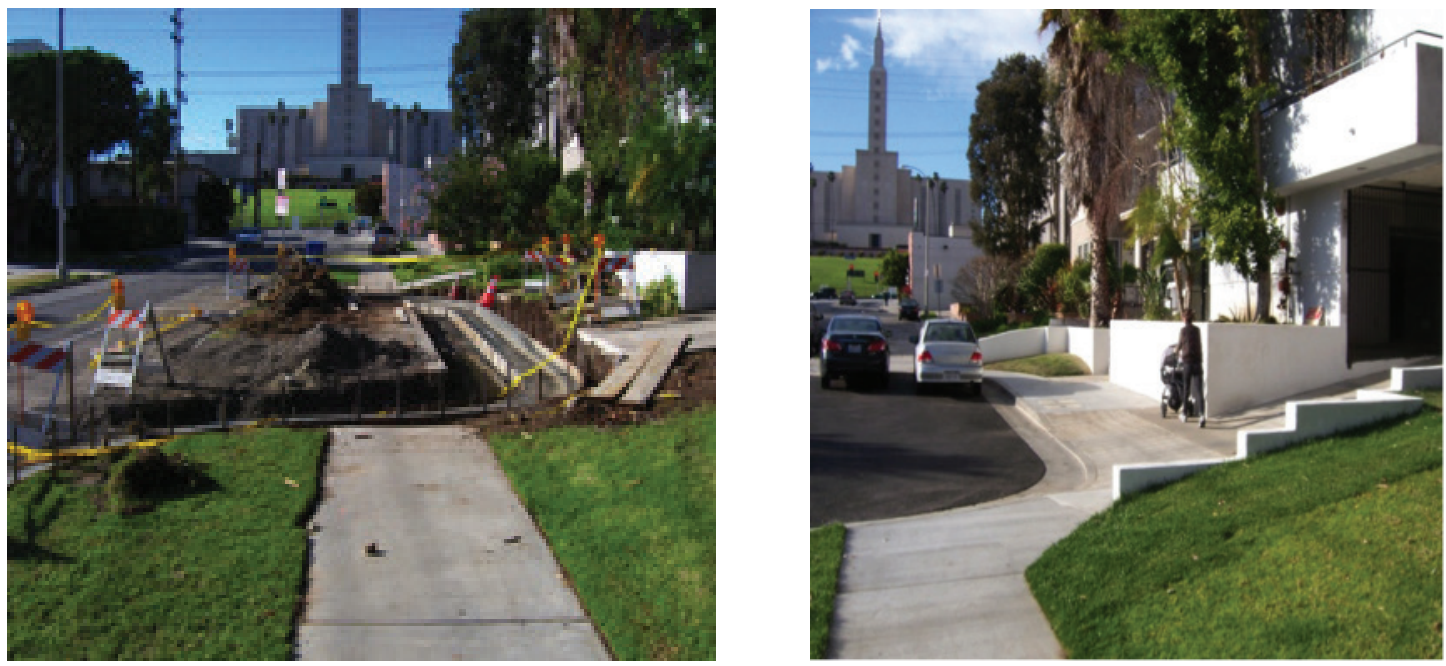

Figure 2: Street dedication and improvement, West Los Angeles. Photos by Donald Shoup.

For dedication to widen the entire street, every parcel would require redevelopment. No properties could be exempt, and the street might need to be devoid of historic buildings. Historic buildings often lack setbacks, and widening streets in front of these buildings could require moving or demolishing them. If just one of these buildings is protected by preservation law or strong public sentiment, full widening might be impossible. Indeed, in 2009 Los Angeles' City Council exempted almost every street in downtown Los Angeles from dedication, because the area's many historic buildings would make full widening impossible (Scott 2009; Los Angeles City Council 2009). The problem persists, however, in the rest of the city. A 2010 report to the city's Department of Transportation noted that even outside the downtown, the city's desire to re-use historic commercial buildings as housing "is often in direct contrast 
with the desire to implement the highway development standards in...the [city's] Transportation Element" (Fehr and Peers 2010, p. 10).

\subsection{Land lost to dedication}

I use the same random sample of dedications to estimate the amount of land lost to dedication. I do so by first using dedication records to estimate the size of the dedication, and then using ZIMAS to estimate the pre-dedication lot size. Computing the former as a share of the latter shows that the average dedication took 5 percent of the lot, while the median dedication took 4 percent. The standard deviation was also 4 percent. Only seven developments surrendered more than 20 percent of their area, while one lost the legal maximum of 25 percent.

How much housing is lost when 5 percent of a lot is dedicated? The answer varies with a parcel's size, configuration, and allowable density. On larger sites, even small proportional decreases can result in substantially less housing. Conversely, developers of smaller sites will lose fewer units, but might also have less flexibility to adjust to lost buildable area. The average size for parcels zoned for multifamily housing in Los Angeles is over 153,600 square feet, but this figure is heavily influenced by some extremely large parcels: the median is just over 27,000 square feet. The average size of a lot in my sample was 24,300 square feet-much closer to the median, although 6 percent of the lots were larger than 60,000 square feet.

Table 3 shows how dedication can reduce housing on a site using the Vermont-Wilshire Towers, a large residential development in central Los Angeles. The towers had a pre-dedication area of about 93,000 square feet, on a lot zoned for dwelling units of 200 square feet. The original plans called for 464 housing units.

The city, however, took more than 6,000 square feet in dedications-a 17-foot-wide strip of land on one side and a two-foot-wide strip on another. The dedications reduced the lot area by about 6 percent (a bit above the sample average) and reduced buildable area from 600,000 to 517,000 square feet. Because the buildable area is used to calculate the permitted floor area, the number of allowable units fell 7 percent, from 464 to 431, even though the permitted density did not change. Thus the dedication, not the permitted density, became a binding limit on the site's housing density. (A simple solution to this problem would be to allow developers to base buildable area on pre-dedication lot size, but Los Angeles does not do this).

Table 3: Street dedication, floor area and allowable units, Vermont-Wilshire Towers

\begin{tabular}{lcc}
\hline & Before Street Dedications & After Street Dedications \\
\hline Lot Area (sq ft) & 92,920 & 86,122 \\
Permitted FAR & 6 & 6 \\
Permitted Floor Area (sq ft) & 557,520 & 516,732 \\
Allowable Density & 200 & 200 \\
Allowable Units & 464 & 431 \\
\hline
\end{tabular}

Source: Craig Lawson \& Co. 2006

Dedication also imposes the cost of physically widening the street. Determining the average cost of a widening is difficult, because the cost of new street space varies tremendously by parcel. Guo and Schloeter (2011) report that residential suburban streets cost between $\$ 8.20$ and $\$ 11.10$ per square foot. But widening an existing urban street can cost much more if it involves moving traffic signals, utility poles, and fire hydrants. Moving a utility pole can cost between $\$ 2,000$ and $\$ 200,000$, depending on 
the pole's material, the depth at which it is buried, and whether it has a switch or transformer attached (Baye 2012).

I had informal conversations with six developers who had dedicated land in Los Angeles-a small sample of convenience- and these conversations convinced me there is no accurate way to estimate the average cost of street widening. The bonds developers must post are likely inaccurate guides, for two reasons. First, the bonds cover all required improvements, not just street improvements, so they might also include retaining walls, open space, and so forth. Second, because developers prefer to post the smallest bond possible, they may underestimate the costs associated with improvement.

The most that can be said is that widenings can be quite burdensome, and their burden is often greatest on small parcels, where the cost can be spread over fewer units. Figure 3, for example, shows a 6,000 -square-foot dedication where the improvement cost about $\$ 450,000$, and required moving utility poles, trees, a fire hydrant, the curb and gutter, and the sidewalk itself. The developer had originally proposed 10 units but says the dedication and improvement costs reduced that number to nine. This statement may or may not be correct, of course, but in either case the improvement cost about $\$ 175$ per square foot of street, or about $\$ 50,000$ per unit.
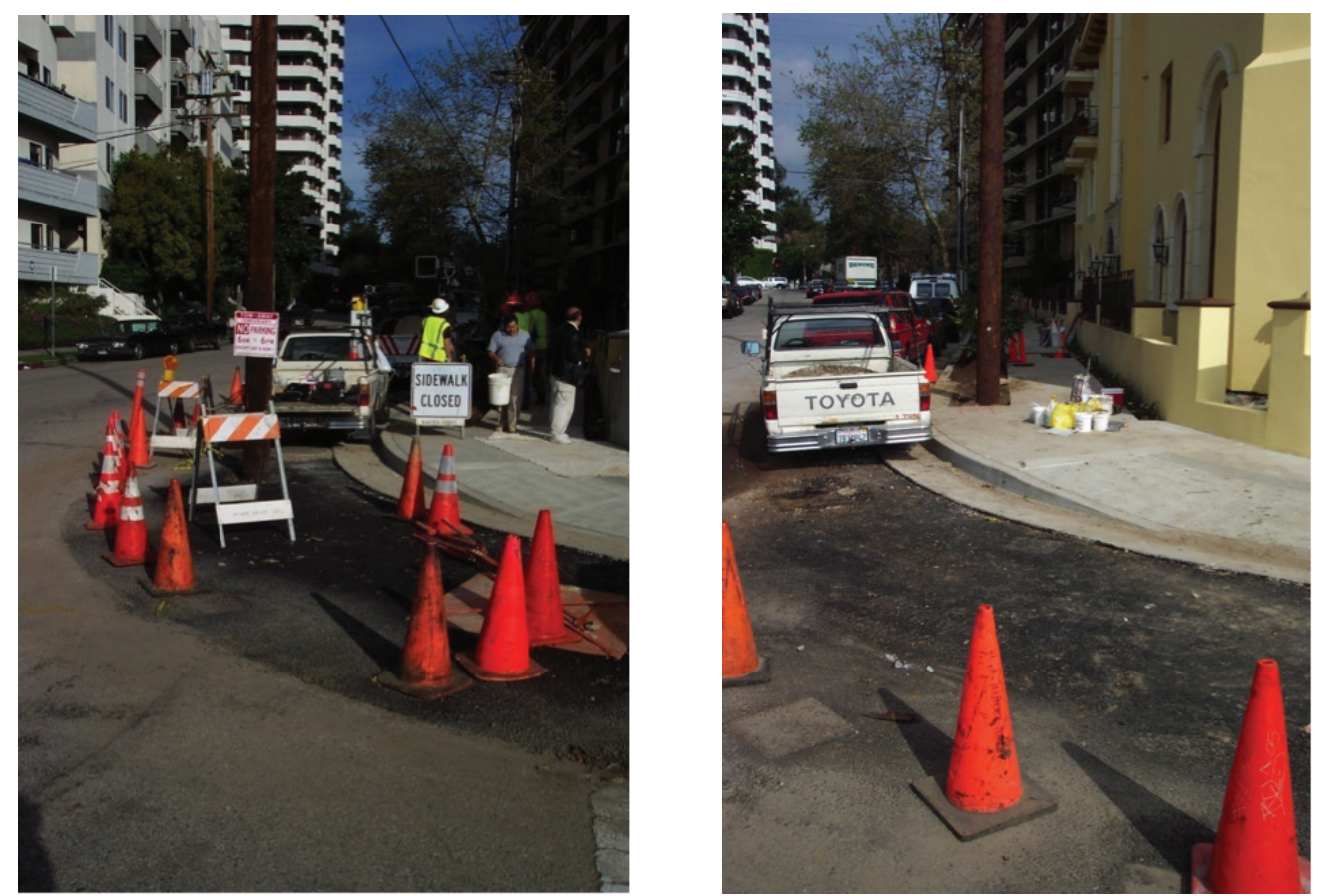

Figure 3: Street improvement that required moving a telephone pole. Photo by Donald Shoup.

In contrast, the developer of a 27 -unit property paid $\$ 300,000$ to convert 2,225 square feet of the existing parkway into new street space (and relocated three utility poles). This cost $\$ 134$ per square foot, but only $\$ 11,100$ per unit. And in 2006, the developer of two residential towers in downtown Los Angeles won permission to pay the city the equivalent cost of a required widening, rather than widen the street itself (the developers wanted a wide sidewalk). ${ }^{8}$ The payment was $\$ 605,033$ : About $\$ 84$ per square foot, but only about $\$ 65$ per unit (Estolano 2006). Thus while improvements can be burdensome, sufficient density can help spread that burden. But if dedication reduces buildable area, it can reduce density as well, making the improvement less affordable. In sum, the evidence here is equivocal. Dedication imposes an additional cost on developers, but directly estimating how that cost translates

\footnotetext{
${ }^{8}$ The city's redevelopment authority, which was subsidizing the development, actually paid the fee.
} 
into housing units is difficult with existing data. However, because housing in Los Angeles is so expensive, and because the mobility benefits of wider streets are likely small, almost any lost housing suggests that dedication's costs exceed its benefits.

\section{$5 \quad$ The persistence of dedication}

What conditions make dedication go wrong, and why have they not been fixed? Political scientists and organizational theorists have long examined the conditions under which regulation goes astray (e.g., Downs 1967; Wilson 1998). This research yields a common thread: Rules work best when an agency's desired outcomes are unambiguous and easily measured. Parcel-level mitigation does not meet these criteria. Broadly speaking, mitigation seeks to reduce congestion or increase mobility. Congestion and mobility, however, are at best difficult to measure, as evidenced by long-running arguments over common metrics of traffic delay (Cortight 2010; Littman 2011; Feigenbaum 2012). And because mitigation often seeks to reduce not just congestion, but congestion originating from a particular parcel or street segment, measurement becomes more difficult still.

When an agency's goals are hard to measure, its rules are less likely to advance the goals and more likely to become them: The process becomes the agency's product. This shift from goals to processes often occurs subtly and results not just from organizational pressures but also from cognitive biases that afflict people generally. Both Kahneman (2011) and Tetlock and Gardner (2015) document the tendency of people and organizations confronted with hard questions to answer easier questions instead, often without noticing they have done so. With mitigation, it is easier to know if the street was widened than to know if congestion fell as a result.

This tendency for rules to displace goals is exacerbated with parcel-based mitigations, because the agency that enforces the rules is not the agency concerned with the goal. Dedication tries to change transportation outcomes through the process of approving housing. This means transportation engineers have only an indirect role in the process. While engineers recommend that planners require widening, it is planners-who have less expertise and jurisdiction over streets-who enforce the rule. The planners, moreover, only have authority over developers before building permits are granted, meaning that by definition planners can only enforce the process, not the desired outcome. Any change in congestion will occur only after the development and the mitigation are complete. It is the engineers' job to recommend the widening, the planners' job to enforce it, and no one's job to see if it worked.

These factors combine not just to set the process astray, but also to impede its reform, because with no one concerned if widening works, no one has much reason to change it if it doesn't. While developers doubtless dislike the law, they often lack strong incentives to oppose it. The evidence suggests that mitigation laws have low social benefits and higher social costs; more is lost in housing than is gained in mobility. But developers evaluate land-use regulations based on private benefits and costs. Developers want to finish their particular projects, not reduce congestion or improve housing affordability citywide (indeed, developers might prefer that housing be less affordable). Developers will thus challenge a dedication only if the expected cost of compliance exceeds the expected cost of appealing (in time, money, uncertainty, and political capital).

As it happens, appeals in Los Angeles are expensive. Developers are sometimes unsure where to direct appeals - the engineers or the planners (Eastsider 2011; Williams 2008). Moreover, my conversations with planners and engineers suggest that even when both groups believe a widening could be unnecessary, neither wants to "go first" and waive the dedication. Planners in these instances would prefer that $\mathrm{BOE}$ engineers not recommend the widening, but the engineers, because they do not work in public hearings, believe it would be improper for them to ignore the city's street standards. They argue instead that they are obligated to recommend the widening, but that planners are not obligated to 
take the recommendation. Politically, however, this may be a hard course for planners to take. Planners work in public hearings, often attended by neighbors opposed to new development, and may thus be reluctant to release developers from a mitigation that engineers have recommended, and that is based on the city's technical standards.

If planners do not waive widenings, developers must appeal to the city council. Yet the council's main relief from dedication is reclassifying street segments-for example, converting a street segment too narrow for an arterial into a secondary highway, and thus making its current width conform to its new category. Street reclassification, however, requires amending the city's General Plan-a lengthy, expensive and uncertain process that involves a minimum of four public hearings.

What results is a collective action problem. It will often be individually rational for developers to widen the streets in front of their parcels; they will gain more through faster approval than they lose in ceded land. Yet it may be collectively irrational for these widenings to occur, because cumulatively the city loses more in housing than it gains in mobility. Without developers challenging the law, however, planners have no incentive to re-examine it, because the planners, like the developers, are focused more on the parcel than the city (or even the street). The planners' concern is whether each individual developer currently under review widens a particular segment of street, not the citywide housing or mobility consequence of those widenings over time. As such, the process persists.

\section{Conclusion}

Parcel-level traffic mitigation has the trappings of science. Cities use predictions and manuals purporting to show how much traffic a given development will create, or how much traffic a given street will carry, and then apply formulas that translate these predictions into the various increases in road capacity necessary to offset those vehicle trips. In this way, developers are held responsible for the traffic they create.

There is, however, little reason to believe developers "create" traffic, and little reason to think planners can accurately predict it at the parcel level. Cities adopted parcel-level mitigations not because they were shown to work, but because other ways to address congestion were politically or fiscally unfeasible. In the case of Los Angeles' highway dedication law, the law's proponents conceded from the outset that it was unlikely to work. The evidence I present here suggests that the standards underlying the law are often in error, and in some cases simply unverifiable. Such immunity to measurement is antithetical to sound policy, but — perversely — the pursuit of a largely unmeasurable goal helps ensure the law's persistence, because it leads planners to largely ignore the law's nominal purpose and instead emphasize its measurable process. The law, in short, is all tree and no forest; while its intent may be to alter outcomes on the network of streets, all of its stakeholders are focused on individual parcels.

Possibly the implementation troubles I have documented are unique to Los Angeles. But to the extent they are not, they add new evidence to the existing case against parcel-level mitigation. The evidence presented here gives little reason to think parcel-level mitigation is doing good, and good reason to think it is doing harm. An optimist might argue that mitigation, despite its flaws, can be a placeholder for more direct approaches to manage congestion, such as higher gasoline taxes, tolls on larger streets, and direct and accurate prices for street parking. But it is also possible that mitigation, by creating an illusion of sophisticated technical standards deployed to battle congestion, actually deters the adoption of simpler and more effective but politically less palatable policies. If mitigation lets cities and voters dodge the reality that solving congestion will likely involve making driving more expensive, and if it impedes housing development as well, then planners may wish to consider abandoning the practice, rather than attempting incrementally to improve it. 


\section{References}

Asabere, P. 1990. The value of a neighborhood street with reference to the cul-de sac. Journal of Real Estate Finance and Economics 13: 185-193.

Baye, R. 2012. The price of a utility pole: $\$ 200,000$. April 4. Washington DC: Washington Examiner.

Ben-Joseph, E. 1995. Residential Street Standards and Neighborhood Traffic Control. Berkeley, CA: University of California at Berkeley, Institute of Urban and Regional Development.

Bottles, S. 1991. Los Angeles and the Automobile. Los Angeles: UC Press.

Brown, J. 2005. A tale of two visions. Journal of Urban History 4: 3-32.

Buttke, C., and E. Arnold. 2003. Rejoinder. Journal of Transportation and Statistics 6(1): 13-17.

California Supreme Court. 1949. Ayres v City Council. 34 Cal 2d 31. June 14.

Chester, M., A. Fraser , J. Matute, C. Flower, and R. Pendyala. Parking infrastructure: A constraint on or opportunity for urban redevelopment? Journal of the American Planning Association 81(4): 268-286.

Cortright, J. 2010. Driven Apart. Cleveland, OH: CEOs for Cities.

County of Los Angeles. 1941. Master Plan of Highways. Report to the Regional Planning District.

Craig Lawson and Co. 2006. Attachment A: Request for discretionary approvals and findings. March 28. Vesting Tentative Tract - 6628B. EAF-2005-8703-EIR. Los Angeles: Craig Lawson and Co.

Duranton, G., and M. Turner. 2011. The fundamental law of road congestion. American Economic Review 101(6): 2616-52.

Downs, A. 2004. Still Stuck in Traffic. Washington, DC: Brookings.

Downs, A. 1967. Inside Bureacracy. Boston: Little, Brown and Company.

Dumbaugh, E. 2005. Safe streets, livable streets. Journal of the American Planning Association 71(3): 283-298.

Eastsider. 2011. Street widening threatens Silver Lake palm trees. Eastsider (blog). http://www.theeastsiderla.com/2011/02/street-widening-threatens-silver-lake-palm-trees/.

Estolano, C. 2006. Adoption of finding for benefit resolution and authorization to transfer $\$ 605,033$ from LA CRA to City of Los Angeles Public Works Trust Fund. LA CRA File 50111, Council File 05-1514 06-0547. Los Angeles: Los Angeles City Council.

Feigenbaum, B. 2012. Texas Transportation Institute knows how to measure congestion. Reason. September 3. http://reason.org/blog/show/texas-transportation-institute-know.

Fehr and Peers. 2010. LA street classification and benchmarking system. Los Angles: LA Department of Transportation.

Fogelson, R. 2003. Downtown. Cambridge, MA: MIT Press.

Glaeser, E. 2004. Housing Supply. Cambridge, MA: NBER Research Reporter.

Guiliano, G. 1995. The weakening transportation-land use connection. ACCESS 6: 3-11.

Guo, Z., and L. Schloeter. 2011. Street standards as parking policy. Journal of Planning Education and Research 33(4): 456-470.

Handy, S. 2013. Smart Growth Trip Generation. Davis: Urban Land Use and Transportation Center of the Institute of Transportation Studies.

Heeb, W. 1961. Staff Report on Proposed Ordinance. June 29. Los Angeles: Los Angeles City Planning Department.

Home, T. 1969. Zoning setback lines: A reappraisal. William and Mary Law Review 10(3): 739-754.

Jakle, J., and K. Sculle. 2004. Lots of Parking. Charlottesville, VA: University of Virginia Press.

Kahnemanm, D. 2011. Thinking, Fast and Slow. New York: Farrar, Strauss and Giroux.

Kim, K., S. J. Park, and Y.-J. Kweon. 2007. Highway traffic noise effects on land price in an urban area. 
Transportation Research Part F 12(4): 275-280.

Krekorian, P. 2014. Motion to waive street widening on Riverton Avenue. Los Angeles City Council. Council File 14-1283. http://clkrep.lacity.org/onlinedocs/2014/14-1283_ca_10-14-14.pdf.

Littman, T. 2011. Faulty assumptions in the TTI Urban Mobility Report. Planetizen (blog). October 2. http://www.planetizen.com/node/51680.

Los Angeles Department of Transportation. 2010. Traffic Safety Policies and Procedures. July. Los Angeles: LA DOT.

Los Angeles City Council. 2009. Street width and sidewalk standards/Central City area. Council File Number 05-1514. October 15. Los Angeles: LA City Council.

Los Angeles Times. 1929. Pasadena given clear roadway. August 1. A7. Los Angeles: Los Angeles Times.

Los Angeles Traffic Commission. 1929. Major Street Traffic Plan. City of Los Angeles. http://libraryarchives.metro.net/DPGTL/trafficplans/1924_traffic_street_plan.pdf.

Manville, M., A. Beata, and D. Shoup. 2013. Turning housing into driving: Parking requirements and density in Los Angeles and New York. Housing Policy Debate 23(2): 350-375.

Mayo, J. 1993. The American Grocery Store. Santa Barbara, CA: Praeger.

McShane, C. 1994. Down the Asphalt Path. New York: Columbia University Press.

Merton, R. 1957. Social Theory and Social Structure. Glencoe, IL: Free Press.

Millard-Ball, A. 2015. Phantom trips: Overestimating the impact of new development. Journal of Transportation and Land Use. 8(1): 31-40.

Monlux, J. 1957. Letter to City Council of Los Angeles. Council File 82-318. Los Angeles: Los Angeles City Council.

Municipal Journal. 1907. Street Traffic Regulations. November 20. 577.

Newstrum, R. 1961. Planning analyst report on proposed street dedication ordinance. September 28. W.A. 18-18.

No Author. 1924. Traffic and City Streets. Public Works.

Norton, P. 2008. Fighting Traffic. Cambridge, MA: MIT Press.

Olmsted, F. L., Jr. 1910. Introduction: Basic principles of city planning. Address to the Second National Conference on City Planning and Congestion of Population. In City Planning: A Series of Papers Presenting the Essential Elements of a City Plan, edited by John Nolen, 1-18. New York: D. Appleton and Company, 1916. Also available at http://urbanplanning.library.cornell.edu/DOCS/olmst_16.htm.

Ostrom, E. 1990. Governing the Commons. Cambridge, UK: Cambridge University Press.

Proceedings of the National Conference on City Planning. 1923. Internet. http://archive.org/stream/ proceedingsofnat15natirich/proceedingsofnat15natirich_djvu.txt.

Roberts, J. 1961. Letter from Director of City Planning to Mayor Sam Yorty, Council File 82398, 03062, 93665. July 6. Los Angeles: Los Angeles City Council.

Shoup, D. 2003. Truth in transportation planning. Journal of Transportation and Statistics 6(1): 1-16.

Shoup, D. 1999. The trouble with minimum parking requirements. Transportation Research Part A 33: 549-574.

Schneider, R., S. Handy, and K. Shafizadeh. 2015. Method to adjust Institute of Transportation Engineers vehicle trip generation estimates in smart growth areas. Journal of Transportation and Land Use. 8(1): 69-83.

Scott, A. 2009. Walkable by design. January 9. Los Angeles: Los Angeles Downtown News.

Southworth, M., and E. Ben-Joseph. 1997. Streets and the Shaping of Towns and Cities. New York: McGraw Hill.

Spayde, F. O. 1925. Eighty million for city streets. January 1. Los Angles: Los Angeles Times.

Swift, P., M. Painter, and D. Goldstein. 2006. Residential street typology and injury accident rrequency. 
Originally presented at the Congress for the New Urbanism. Denver, Colorado, 1997. http://massengale.typepad.com/venustas/files/swiftsafetystudy.pdf.

Tetlock, P., and D. Gardner. 2015. Superforecasting. New York: Crown.

Wilhelmsson, M. 2000. The impact of traffic noise on the values of single-family homes. Journal of Environmental Planning and Management 43(6): 799-815.

Wilson, J. 1998. Bureaucracy. New York: Basic.

Wachs, M. 1990. Regulating traffic by controlling land use. Transportation 16: 241-256.

Williams, L. 1923. Traffic in Los Angeles. November 25. Los Angeles: Los Angeles Times.

Williams, J. 2008. Along the Wilshire Corridor. August 11. Los Angeles: Curbed LA. 